\title{
PENGARUH PUPUK DAUN DAN ZPT TERHADAP PERTUMBUHAN DAN PRODUKSI TOMAT (Solanum lycopersicum L)
}

\author{
Eliakim Purba \\ Universitas Amir Hamzah \\ Eliakim_purba@yahoo.com
}

\begin{abstract}
ABSTRAK
Penelitian bertujuan untuk mengetahui pengaruh pupuk daun dan ZPT terhadap pertumbuhan dan produksi tomat, serta interaksi kedua perlakuan tersebut. Penelitian menggunakan Rancangan Acak Kelompok (RAK) Pola Faktorial, yang terdiri dari 2 faktor yaitu : Faktor pupuk daun ( Bayfolan ) dengan notasi (D) yang terdiri dari 4 taraf : $\mathrm{D}_{0}(0 \mathrm{ml} / \mathrm{l}$ air), $\mathrm{D}_{1}\left(1 \mathrm{ml} / \mathrm{l}\right.$ air), $\mathrm{D}_{2}\left(2 \mathrm{ml} / \mathrm{l}\right.$ air), dan $\mathrm{D}_{3}(3 \mathrm{ml} / \mathrm{l}$ air). Faktor ke dua yaitu ZPT ( Viva Gibd ) dengan notasi $(\mathrm{H})$ yang terdiri dari 3 taraf yaitu : $\mathrm{Z}_{1}(0 \mathrm{ml} /$ liter air $), \mathrm{Z}_{2}(0,2 \mathrm{ml} /$ liter air), dan $\mathrm{Z}_{3}(0,4 \mathrm{ml} / \mathrm{liter}$ air $)$. Untuk menggambarkan pertumbuhan dan produksi tomat dilakukan pengamatan terhadap parameter tinggi tanaman, diameter batang, jumlah bunga produktif, jumlah buah per tanaman, produksi per plot, dan produksi per hektar. Hasil penelitian menunjukkan pupuk daun Bayfolan berpengaruh nyata terhadap tinggi tanaman pada umur 30 HST, produksi per plot, dan produksi per hektar. Perlakuan terbaik dijumpai pada $\mathrm{D}_{3}$ yaitu 3 $\mathrm{ml} /$ liter air. ZPT berpengaruh tidak nyata terhadap semua parameter pengamatan yaitu tinggi tanaman, diameter batang, jumlah bunga produktif, jumlah buah per tanaman, produksi per plot, dan produksi per hektar. Interaksi antara pupuk daun bayfolan dan ZPT berpengaruh nyata terhadap Diameter Batang pada umur 30 HST. Perlakuan interaksi antara pupuk daun Bayfolan kontrol (0 ml/ liter air) dan 0,2 ml/ liter air. Berdasarkan hasil penelitian untuk mendapatkan pertumbuhan dan produksi tanaman tomat yang baik dianjurkan menggunakan pupuk daun Bayfolan dengan konsentrasi $3 \mathrm{ml} /$ liter air, atau menggunakan interaksi antara pupuk daun bayfolan dan ZPT yaitu kontrol $(0 \mathrm{ml} /$ liter air) dan 0,2 $\mathrm{ml} /$ liter air.
\end{abstract}

Keyword : Pupuk Daun, ZPT, Pertumbuhan dan Produksi Tomat 


\section{PENDAhUluan}

Tanaman tomat (Solanum lycopersicum L) berasal dari negara Peru dan Ekuador, kemudian menyebar ke seluruh Amerika, terutama ke wilayah yang beriklim tropik, sebagai gulma. Kata tomat berasal dari bahasa Aztek, salah satu suku Indian yaitu xitomate atau xitotomate. Penyebaran tanaman tomat ini dilakukan oleh burung yang makan buah tomat dan kotorannya tersebar kemana-mana. Penyebaran tomat ke Eropa dan Asia dilakukan oleh orang Spanyol. Tomat ditanam di Indonesia sesudah kedatangan orang Belanda. Dengan demikian, tanaman tomat sudah tersebar ke seluruh dunia, baik di daerah tropik maupun subtropik (Eko, 2013).

Produksi buah tomat di Indonesia meningkat sepanjang tahun. Sampai saat ini, Indonesia masih melakukan import buah tomat untuk memenuhi kebutuhan dalam negeri. Berdasarkan data statistika Badan Pusat Statistik tahun 2013. Indonesia masih melakukan import buah tomat meskipun nilainya yang tidak terlalu besar. Peningkatan produktivitas tomat diperlukan agar import tidak dilakukan lagi. Salah satu jenis tanaman tomat yang diminati oleh masyarakat. Indonesia adalah tomat cherry. Pengembangan sistem budidayanya dirasa perlu dilakukan (Edu, 2015).

Pupuk daun Bayfolan merupakan pupuk anorganik yang dirancang sebagai makanan seimbang yang lengkap dengan unsur hara makro (N, P, K Ca, Mg, dan S) dan mikro ( $\mathrm{B}, \mathrm{Fe}$, $\mathrm{Mn}, \mathrm{Cu}, \mathrm{Zn}, \mathrm{Mo}, \mathrm{Co}$, dan $\mathrm{Cl}$ ) untuk berbagai jenis tanaman. Selain itu pupuk ini juga mengandung antibiotik (pemusnah kuman) serta vitamin yang berfungsi mengaktifkan sel-sel yang rusak atau mati, mendorong pertumbuhan sel-sel baru, merangsang pertumbuhan batang, daun lebih menghijau serta bunga lebih meningkat (Ashfi, 2004).

Hasil penelitian Hamidah (2013), menyimpulkan bahwa pemberian pupuk daun Bayfolan berpengaruh nyata terhadap jumlah daun umur 4 minggu setelah tanam dengan konsentrasi $1,5 \mathrm{ml} / 1$ air.

Tomat juga merupakan komoditas hortikultura unggul, namun persentase fruit set seringkali rendah. Pemberian GA3 pada tomat dapat menimbulkan buah partenokarpi. Partenokarpi adalah mekanisme pembentukan buah tanpa melalui proses polinasi dan fertilisasi Upaya pembentukan buah partenokarpi melalui induksi giberelin dimaksudkan untuk memperbaiki kualitas bentuk, ukuran buah besar, jumlah biji yang sedikit serta lebih stabil bentuk dan ukuran. Giberelin (GA3) berfungsi untuk mendorong perkembangan biji, pemanjangan batang dan pertumbuhan daun serta mendorong pembungaan dan perkembangan buah (Alpano, 2014).

\section{Tujuan Penelitian}

Untuk mengetahui pengaruh pupuk daun dan ZPT terhadap pertumbuhan dan produksi tomat serta interaksi kedua perlakuan tersebut.

\section{Hipotesis Penelitian}

1. Pupuk daun berpengaruh terhadap pertumbuhan dan produksi tanaman tomat.

2. ZPT berpengaruh terhadap pertumbuhan dan produksi tanaman tomat.

3. Terdapat interaksi antara pupuk daun dan ZPT terhadap pertumbuhan dan produksi tanaman tomat. 


\section{TINJAUAN PUSTAKA}

\section{Botani Tanaman Tomat dan Klasifikasi}

Tomat (Solanum lycopersicum L) merupakan sayuran buah yang dipanen dan dikonsumsi bagian buahnya, dengan klasifikasi ilmiah sebagai berikut (Herry, 2009) :

$\begin{array}{ll}\text { Divisio } & \text { : Spermatophyta } \\ \text { Claas } & \text { : Dicotyledoneae } \\ \text { Ordo } & \text { : Tubiflorae } \\ \text { Famili } & \text { : Solanaceae } \\ \text { Genus } & \text { : Solanum } \\ \text { Spesies } & \text { : Solanum lycopersicum L. }\end{array}$

\section{Syarat Tumbuh \\ Iklim dan Suhu}

Suhu yang terbaik bagi tanaman pertumbuhan tomat adalah $23^{\circ} \mathrm{C}$ pada siang hari dan $17^{\circ} \mathrm{C}$ pada malam hari. Selisihnya adalah $6^{\circ} \mathrm{C}$. Suhu tinggi yang diikuti kelembapan relatif yang tinggi dapat menyebabkan penyakit daun berkembang, sedangakan kelembapan yang relatif rendah dapat menganggu pembentukan buah. intensitas sinar matahari berkisar antara 10-12 jam / hari (Herry, 2009).

\section{Topograpi}

Tanaman tomat dapat tumbuh dengan baik pada daerah dengan ketinggian 100-1000 meter di atas permukaan laut, dengan intensitas cahaya matahari yang tinggi dan cutah hujan rata-rata 100-220 mm/tahun (Novik, 2012).

\section{Sinar Matahari}

Cahaya matahari sangat diperlukan dalam proses fisiologi tanaman untuk membentuk bagian vegetatif (batang, daun, dan daun), dan bagian generatif (bunga, buah, dan biji). Kebutuhan sinar matahari sebagai sumber energi fotosintesis yang tergantung pada lamanya penyinaran.untuk mendapatkan hasil yang baik, tanaman tomat memerlukan penyinaran matahari sepanjang hari di tempat yang terbuka (sekitar 8 jam per hari) (Bambang, 2008).

\section{Tanah}

Kondisi tanahyang cocok untuk budidaya tomat adalah tanah dengan tekstur sedikit mengandung pasir, banyak kandungan liat, serta mengandung banyak bahan organik. Tomat responsif terhadap tanah yang miskin unsur hara. Selain itu, tomat tumbuh secara optimal pada tanah dengan pH 5-7 (Dudy, 2010).

\section{Pupuk Daun}

Untuk meningkatkan produksi tanaman maka pemberian jenis dan dosis pupuk harus diperhatikan, agar dapat mencapai hasil produksi yang memuaskan. Pupuk adalah bahan organik ataupun bahan anorganik yang diperoleh secara alami ataupun dari sintesis beraneka macam bahan dan ditambahkan ke dalam tanah untuk memberikan unsur esensial yang diperlukan tanaman untuk pertumbuhan dan perkembangannya (Arif, 2013)

Pemupukan biasanya melalui akar atau tanah tetapi dapat juga dilakukan melalui bagian tanaman lain seperti daun dan batang. Pupuk daun termasuk pupuk buatan yang cara pemberiannya pada tanaman melalui penyemprotan ke daun. Ada satu kelebihan yang paling mencolok dari pemupukan melalui daun, yakni penyerapan hara yang diberikan berjalan lebih cepat dibandingkan dengan pemberian melalui akar tanaman. Tanaman lebih cepat menumbuhkan tunas dan tanah tidak rusak atau lelah. Sehingga pemupukan lewat daun 
dipandang lebih cepat dibandingkan dengan pemberian melalui akar tanaman. Tanaman lebih cepat menumbuhkan tunas dan tanah tidak rusak atau lelah (Susmawati, 2014).

Bayfolan merupakan pupuk daun lengkap berbentuk cairan berwarna hijau jernih untuk pemupukan pada tanaman buah-buahan, hias, sayuran serealia, tanaman perkebunan dan lain-lain. Komposisi hara yang terkandung dalam Bayfolan adalah Nitrogen - N 11\%, Fosfor - P2O5 8\%, Kalium - K2O 6\%, Serta unsur - unsur micro besi, boron, kobalt, mangan, molibdenum, seng dan tembaga (Sandy, 2011). Menurut hasil penelitian Asnijar, (2013), bahwa pemberian Bayfolan dengan konsentrasi 1 dan $2 \mathrm{ml} / 1$ air dapat meningkatkan pertumbuhan dan hasil tanaman cabai.

\section{ZPT}

ZPT tanaman adalah senyawa - senyawa organik tanaman yang dalam konsentrasi yang rendah mempengaruhi proses -proses fisiologis. Proses-proses fisiologis ini terutama tentang proses pertumbuhan, differensiasi dan perkembangan tanaman. Proses - proses lain seperti pengenalan tanaman, pembukaan stomata, translokasi dan serapan hara dipengaruhi oleh ZPT tanaman (Sitiumi, 2013).

Viva gibd merupakan ZPT tumbuh yang memiliki bahan aktif giberelin. ZPT Giberelin adalah ZPT tumbuhan yang berperan dalam proses perkembangan dan perkecambahan. Giberelin akan merangsang pembentukan enzim amilase yang berfungsi untuk memecah senyawa amilum yang terdapat di endosperm (cadangan makanan) menjadi senyawa glukosa. Glukosa tersebut menjadi sumber energi bagi pertumbuhan tanaman. ZPT ini berfungsi secara sinergis (bekerja sama) dengan ZPT auksin. Selain itu, ZPT giberelin juga memiliki fungsi dalam proses pembentukan serbuk sari (polen), memperbesar ukuran buah, merangsang pembentukan bunga, dan mengakhiri masa dormansi biji. Giberelin dengan konsentrasi tinggi juga akan merangsang pembentukan akar (Mulanovich, 2013).

ZPT giberelin adalah suatu zat yang diperoleh dari salah satu jenis jamur yang hidup sebagai parasit pada padi di Jepang. Jamur tersebut adalah Gibberella fujikuroi. Fungsi ZPT giberelin mempengaruhi pemanjangan dan pembelahan sel, memengaruhi perkembangan embrio dan kecambah, menghambat pembentukan biji, mempengaruhi pemanjangan batang, dan memengaruhi pertumbuhan dan perkembangan akar, daun, bunga, dan bunga (Zaka, 2015).

Berbeda dengan klasifikasi auksin yang diklasifikasikan berdasarkan fungsi, giberelin diklasifikasikan berdasarkan struktur serta fungsi. Semua giberelin yang berasal dari kerangka ent-gibberellane. Para giberelin diberi nama GA1 - GAn di urutan penemuan. Asam giberelat, yang merupakan giberelin pertama yang secara struktural ditandai, adalah GA3. Giberelin adalah diterpen disintesis dari asetil CoA melalui jalur asam mevalonat. Mereka semua memiliki baik 19 atau 20 unit karbon dikelompokkan menjadi empat atau lima sistem cincin. Giberelin diyakini disintesis dalam jaringan muda dari tunas dan juga biji berkembang. Tidak pasti apakah jaringan akar muda juga memproduksi giberelin. Ada juga beberapa bukti bahwa daun dapat menjadi sumber beberapa biosintesis (Sridianti, 2012).

Hasil penelitian Zaura, (2014), menunjukkan pemberian giberelin sampai 200 ppm $(0,2 \mathrm{ml} /$ liter air) berpengaruh nyata dalam mengurangi jumlah biji dan mempercepat umur panen tetapi berpengaruh tidak nyata terhadap panjang tanaman, jumlah daun, umur berbunga dan diameter buah tanaman semangka.

ZPT tanaman dapat diartikan luas, baik yang buatan maupun yang asli serta yang mendorong ataupun yang menghambat pertumbuhan. Pada kadar rendah tertentu ZPT/zat tumbuh akan mendorong pertumbuhan, sedangkan pada kadar yang lebih tinggi akan 
menghambat pertumbuhan, meracuni, bahkan mematikan tanaman. Pemaham

ap ZPT pada masa kini telah membantu peningkatan hasil pertanian dengan ditemukannya perbagai macam zat sintetis yang memiliki pengaruh yang sama dengan ZPT alami (Prasetyo, 2011).

\section{METODE PENELITIAN}

\section{Metode Penelitian}

Metode yang digunakan dalam penelitian ini adalah Rancangan Acak Kelompok (RAK) pola faktorial, yang terdiri dari 2 faktor yaitu :

1. Faktor pupuk daun ( Bayfolan ) dengan notasi (D) yang terdiri dari 4 taraf yaitu :

$\mathrm{D}_{0} \quad: 0 \mathrm{ml} / \mathrm{liter}$ air

$\mathrm{D}_{1} \quad: 1 \mathrm{ml} / \mathrm{liter}$ air

$\mathrm{D}_{2} \quad: 2 \mathrm{ml} / \mathrm{liter}$ air

$\mathrm{D}_{3}: 3 \mathrm{ml} / \mathrm{liter}$ air

2. Faktor ZPT ( Viva Gibd ) dengan notasi (Z) yang terdiri dari 3 taraf :

$\mathrm{Z}_{1} \quad: 0 \mathrm{ml} /$ liter air

$\mathrm{Z}_{2} \quad: 0,2 \mathrm{ml} /$ liter air

$\mathrm{Z}_{3} \quad: 0,4 \mathrm{ml} /$ liter air

Dengan demikian akan diperoleh 12 kombinasi perlakuan, dengan kombinasi seperti disajikan pada tabel 1 berikut :

Tabel 1. Susunan Kombinasi Perlakuan Antara Pupuk Daun dan ZPT terhadap Pertumbuhan dan Produksi Tomat (Solanum lycopersicum L).

\begin{tabular}{|c|c|c|c|}
\hline No & $\begin{array}{c}\text { Kombinasi } \\
\text { Perlakuan }\end{array}$ & $\begin{array}{c}\text { Pupuk Daun Bayfolan } \\
(\mathrm{ml} / \text { liter air })\end{array}$ & $\begin{array}{c}\text { ZPT Viva Gibd } \\
(\mathrm{ml} / \text { liter air })\end{array}$ \\
\hline 1 & $\mathrm{D}_{0} \mathrm{Z}_{1}$ & 0 & 0 \\
2 & $\mathrm{D}_{0} Z_{2}$ & 0 & 0,2 \\
3 & $\mathrm{D}_{0} Z_{3}$ & 0 & 0,4 \\
4 & $\mathrm{D}_{1} \mathrm{Z}_{1}$ & 1 & 0 \\
5 & $\mathrm{D}_{1} Z_{2}$ & 1 & 0,2 \\
6 & $\mathrm{D}_{1} Z_{3}$ & 1 & 0,4 \\
7 & $\mathrm{D}_{2} Z_{1}$ & 2 & 0 \\
8 & $\mathrm{D}_{2} Z_{2}$ & 2 & 0,2 \\
9 & $\mathrm{D}_{2} Z_{3}$ & 2 & 0,4 \\
10 & $\mathrm{D}_{3} Z_{1}$ & 3 & 0 \\
11 & $\mathrm{D}_{3} Z_{2}$ & 3 & 0,2 \\
12 & $\mathrm{D}_{3} Z_{3}$ & 3 & 0,4 \\
\hline
\end{tabular}

Setiap perlakuan di ulang 3 (tiga) kali, sehingga diperoleh 36 satuan percobaan, setiap satuan percobaan terdiri dari 4 (empat) tanaman dan 2 (dua) tanaman dijadikan sampel.

Model matematika yang digunakan dalam penelitian ini (Adji, 2000) adalah :

Dimana:

$$
\mathrm{Y}_{\mathrm{ijk}}=\mu+\beta_{\mathrm{i}}+\mathrm{D}_{\mathrm{j}}+\mathrm{Z}_{\mathrm{k}}+(\mathrm{DZ})_{\mathrm{jk}}+\varepsilon_{\mathrm{ijk}}
$$

$\mathrm{Y}_{\mathrm{ijk}} \quad=$ Hasil pengamatan yang diperoleh pada perlakuan Pupuk Daun (j) pada taraf ke-D dan ZPT (Z) pada taraf ke-k pada blok ke-i. 
$\mu \quad=$ Nilai tengah.

$\mathrm{B}_{\mathrm{i}} \quad=$ Pengaruh blok ke-i $(\mathrm{i}=1,2$, dan 3$)$.

$\mathrm{D}_{\mathrm{j}} \quad=$ Pengaruh Pupuk Daun ke-j $(\mathrm{j}=1,2,3$ dan 4).

$\mathrm{Z}_{\mathrm{k}} \quad=$ Pengaruh ZPT ke-k $(\mathrm{k}=1,2$, dan 3$)$.

$(\mathrm{DZ})_{\mathrm{jk}} \quad=$ Pengaruh interaksi Pupuk Daun ke-j dan ZPT ke-k.

$\epsilon_{\mathrm{ijk}} \quad=$ Pengaruh error dari perlakuan Pupuk Daun ke-j dan ZPT ke-k pada blok ke-i.

Data hasil pengamatan akan dianalisa dengan analisis sidik ragam/uji $\mathrm{F}$ pada taraf $5 \%$ dan $1 \%$. Jika terdapat pengaruh sangat nyata dan nyata maka akan dilakukan dengan uji lanjutan yakni uji Beda Nyata Terkecil (BNT) taraf 5\%.

Pengamatan

Parameter pertumbuhan yang diamati dalam penelitian ini antara lain :

Tinggi Tanaman $(\mathbf{c m})$

Pengamatan tinggi tanaman diukur dari pangkal batang sampai dengan daun terpanjang setelah diluruskan. Pengukuran dilakukan pada saat tanaman berumur 30 dan 60 hari setelah tanam.

Diameter Pangkal Batang (mm)

Diameter pangkal batang diukur dengan menggunakan jangka sorong. Pengukuran dilakukan pada saat tanaman berumur 30 dan 60 hari setelah tanam.

\section{Jumlah Bunga Produktif}

Jumlah bunga produktif dihitung dari banyaknya bunga yang tumbuh dan menjadi buah, dilakukan pada saat tanaman berumur 30 dan 60 hari setelah tanam.

Jumlah Buah Per Tanaman

Pengamatan jumlah buah per tanaman dilakukan dengan cara menghitung setiap buah yang muncul pada tanaman sampel. Pengamatan dilakukan pada umur 60 HST.

\section{Produksi Per Plot (kg)}

Pengamatan produksi per plot dilakukan pada saat panen, dengan cara menimbang hasil panen pada setiap plot perlakuan.

\section{Produksi Per Hektar (ton)}

Pengamatan produksi per hektar dilakukan pada saat selesai panen, dengan cara mengkomversikan produksi per plot $(\mathrm{kg})$ ke produksi per hektar (ton).

\section{HASIL DAN PEMBAHASAN}

\section{Pengaruh Pupuk Daun Bayfolan \\ Tinggi Tanaman}

Dari pengamatan tinggi tanaman tomat pada umur 30 dan 60 HST disajikan pada Tabel Lampiran 5 dan 7 sedangkan analisis sidik ragamnya masing - masing disajikan pada Tabel Lampiran 6 dan 8.

Hasil analisis sidik ragam menunjukkan bahwa pupuk daun bayfolan berpengaruh nyata terhadap tinggi tanaman pada umur 30 HST, serta berpengaruh tidak nyata terhadap tinggi tanaman pada umur 60 HST. Rata-rata tinggi tanaman tomat akibat pengaruh pupuk daun bayfolan disajikan pada Tabel 2 .

Tabel 2. Rata-rata Tinggi Tanaman (cm) Tomat pada Umur 30 dan 60 HST akibat Perlakuan Pupuk Daun Bayfolan. 


\begin{tabular}{|c|c|c|}
\hline \multirow{2}{*}{$\begin{array}{c}\text { Perlakuan Pupuk } \\
\text { Daun Bayfolan }\end{array}$} & \multicolumn{2}{|c|}{ Tinggi Tanaman $(\mathrm{cm})$} \\
\cline { 2 - 3 } & $30 \mathrm{HST}$ & $60 \mathrm{HST}$ \\
\hline $\mathrm{D}_{0}$ & $55,11 \mathrm{a}$ & 81,08 \\
\hline $\mathrm{D}_{1}$ & $60,86 \mathrm{~b}$ & 83,36 \\
\hline $\mathrm{D}_{2}$ & $59,19 \mathrm{ab}$ & 81,17 \\
\hline $\mathrm{D}_{3}$ & $62,06 \mathrm{~b}$ & 79,39 \\
\hline BNT 0,05 & 5,06 & - \\
\hline
\end{tabular}

Keterangan : - Angka yang diikuti huruf yang sama berbeda tidak nyata pada uji BNT 5\%.

- HST = hari setelah tanam

Tabel 2 menunjukkan tinggi tanaman tomat pada pada umur 30 HST dijumpai pada perlakuan $D_{3}$ yang berbeda nyata tehadap $D_{0}$, dan berbeda tidak nyata terhadap $D_{1}$ dan $D_{2}$. Hal ini diduga karena telah tercukupinya unsur Nitrogen, besi dan Magnesium. Menurut Hamidah (2013) unsur Nitrogen, besi dan Magnesium merupakan penyusun klorofil, dengan adanya klorofil tanaman mampu mengadakan fotosintesis untuk menghasilkan karbohidrat dan protein, yang selanjutnya digunakan untuk proses pembelahan sel dan pembesaran sel. Jadi dengan tersedianya unsur hara nitrogen yang cukup maka pembentukan klorofil juga akan meningkat yang nantinya akan sangat berguna dalam proses fotosintesis, sehingga dapat meningkatkan karbohidrat yang lebih banyak pula. Dengan adanya karbohidrat yang cukup maka proses pembelahan dan pembesaran sel juga meningkat dan pada akhirnya dapat meningkatkan pertambahan jumlah daun dan tnggi tanaman.

\section{Diameter Batang (mm), Jumlah Bunga Produktif, dan Jumlah Buah Per Tanaman.}

Hasil pengamatan diameter batang $(\mathrm{mm})$, jumlah bunga produktif, dan jumlah buah per tanaman tomat disajikan pada Tabel Lampiran 9, 11, 13, dan 15, sedangkan analisis sidik ragam masing-masing disajikan pada Tabel Lampiran 10, 12, 14 dan 16. Hasil analisis sidik ragam menunjukkan bahwa pupuk daun bayfolan berpengaruh tidak nyata terhadap diameter batang (mm), jumlah bunga produktif, dan jumlah buah per tanaman. Rata-rata diameter batang ( $\mathrm{mm}$ ), jumlah bunga produktif, dan jumlah buah per tanaman tomat akibat pengaruh pupuk daun bayfolan disajikan pada Tabel 4.

Tabel 4. Rata - rata Diameter Batang (mm), Jumlah Bunga Produktif, dan Jumlah Buah Per Tanaman Tomat akibat Perlakuan Pupuk Daun Bayfolan.

\begin{tabular}{|c|c|c|c|c|c|}
\hline \multirow{2}{*}{$\begin{array}{c}\text { Pupuk } \\
\text { Daun } \\
\text { Bayfolan }\end{array}$} & \multicolumn{2}{|c|}{$\begin{array}{c}\text { Diameter Batang } \\
(\mathrm{mm})\end{array}$} & \multicolumn{2}{c|}{$\begin{array}{c}\text { Jumlah Bunga } \\
\text { Produktif }\end{array}$} & \multirow{2}{*}{$\begin{array}{c}\text { Jumlah Buah Per } \\
\text { Tanaman }\end{array}$} \\
\cline { 2 - 5 } & 30 HST & 60 HST & 30 HST & 60 HST & \\
\hline $\mathrm{D}_{0}$ & 7,03 & 9,47 & 2,79 & 4,17 & 5,89 \\
\hline $\mathrm{D}_{1}$ & 7,06 & 9,42 & 3,42 & 4,44 & 5,87 \\
\hline $\mathrm{D}_{2}$ & 7,03 & 9,83 & 3,75 & 4,78 & 6,06 \\
\hline $\mathrm{D}_{3}$ & 6,83 & 10,03 & 3,79 & 4,75 & 6,11 \\
\hline BNT 5\% & - & - & - & - & - \\
\hline
\end{tabular}

- $\quad$ HST = hari setelah tanam

Tabel 4 di atas menunjukkan bahwa pemberian pupuk daun Bayfolan berpengaruh tidak nyata terhadap perameter diameter batang $(\mathrm{mm})$, jumlah bunga produktif pada umur 30 dan 60 HST, dan jumlah buah per tanaman. 
Di duga faktor lingkungan yang menjadi penyebab mengapa pupuk daun Bayfolan tidak memberikan pengaruh yang nyata terhadap diameter batang, jumlah bunga produktif, dan jumlah buah per tanaman, hal ini sesuai pendapat Aryu (2012), bahwa faktor lingkungan yang mempengaruhi pertumbuhan dan perkembangan tanaman adalah unsur hara di dalam tanah, suhu, cahaya, air dan kelembapan, serta tanah.

\section{Produksi Per Plot (kg) dan Produksi Per Hektar (ton)}

Dari pengamatan produksi per plot dan produksi per hektar tanaman tomat disajikan pada Tabel Lampiran 19 dan 21, sedangkan analisis sidik ragamnya masing - masing disajikan pada Tabel Lampiran 20 dan 22.

Hasil analisis sidik ragam menunjukkan bahwa pupuk daun Bayfolan berpengaruh nyata terhadap produksi per plot dan produksi per hektar. Rata - rata produksi per plot dan produksi per hektar tanaman tomat akibat pengaruh pupuk daun Bayfolan disajikan pada tabel 3 .

Tabel 3. Rata - rata Produksi Per Plot dan Produksi Per Hektar Tomat akibat Perlakuan Pupuk Daun Bayfolan.

\begin{tabular}{|c|c|c|}
\hline $\begin{array}{c}\text { Pengaruh Pupuk } \\
\text { Daun Bayfolan }\end{array}$ & Produksi Per Plot (kg) & Produksi Per Hektar (ton) \\
\hline $\mathrm{D}_{0}$ & $3,07 \mathrm{a}$ & $9,72 \mathrm{a}$ \\
\hline $\mathrm{D}_{1}$ & $3,86 \mathrm{~b}$ & $12,22 \mathrm{~b}$ \\
\hline $\mathrm{D}_{2}$ & $3,74 \mathrm{~b}$ & $11,82 \mathrm{~b}$ \\
\hline $\mathrm{D}_{3}$ & $4,25 \mathrm{~b}$ & $13,43 \mathrm{~b}$ \\
\hline BNT 0,05 & 0,63 & 2,01 \\
\hline
\end{tabular}

Keterangan : - Angka yang diikuti huruf yang sama berbeda tidak nyata pada uji BNT 5\%.

- $\quad$ HST = hari setelah tanam

Berdasarkan Tabel 3 di atas menunjukkan produksi per plot dan produksi per hektar tomat dijumpai pada perlakuan $\mathrm{D}_{3}$ yang berbeda nyata tehadap $\mathrm{D}_{0}$, dan berbeda tidak nyata terhadap $\mathrm{D}_{1}$ dan $\mathrm{D}_{2}$. Diduga pupuk daun Bayfolan yang diaplikasikan bekerja dengan baik, sehingga unsur - unsur hara yang terkandung di dalam nya dapat diserap dan mendukung pertumbuhan hasil tanaman tomat. Sejalan dengan itu Susmawati (2015), menyatakan bahwa pupuk daun Bayfolan dapat memperbaiki kuwalitas buah, mempercepat dan meningkatkan hasil.

Bayfolan merupakan pupuk daun lengkap, berbentuk cair, produksi Bayer. Kandungan kadar $\mathrm{N} 11 \%$, P2O5 $10 \%$, K2O $6 \%$ dan unsur - unsur hara mikro lainnya yang melengkapi yaitu $\mathrm{Fe}, \mathrm{Mn}, \mathrm{Cu}, \mathrm{Zn}, \mathrm{Co}$, dan zat penyangga. Warna cairannya hijau agak kehitam - hitaman. Dianjurkan sebagai konsentrasi normal 0,2\% $200 \mathrm{cc}$. Bayfolan dilarutkan dalam air / pelarut sebanyak 100 liter. Bayfolan merupakan pupuk cair sebagai bahan makanan secara foliar (daun) dan akar (Omypane, 2011).

\section{Pengaruh ZPT}

Tinggi Tanaman, Diameter Batang, Jumlah Bunga Produktif, Jumlah Buah Per Tanaman, Produksi Per Plot, dan Produksi Per Hektar.

Hasil pengamatan tinggi tanaman, diameter batang, jumlah bunga produktif pada umur 30 dan 60 HST, serta jumlah buah per tanaman, produksi per plot, dan produksi per hektar 
tanaman tomat disajikan pada Tabel Lampiran 5, 7, 9, 11, 13, 15, 17, 19 dan 21, sedangkan analisis sidik ragamnya masing - masing disajikan pada Tabel Lampiran 6, 8, 10, 12, 14, 16, 18, 20 dan 22.

Hasil analisis sidik ragam menunjukkan bahwa pupuk daun bayfolan berpengaruh tidak nyata terhadap semua perameter pengamatan yaitu, tinggi tanaman, diameter batang, jumlah bunga produktif pada umur 30 dan 60 HST, serta jumlah buah per tanaman, produksi per plot, dan produksi per hektar.

Hal ini di duga hormon yang dihasilkan jaringan tubuh tanaman tomat itu sendiri dapat bekerja dengan baik, sehingga pemberian ZPT dari luar tubuh tanaman tidak memberikan pengaruh yang nyata.

Hormon pertumbuhan meliputi auksin, giberelin, sitokinin, etilen dan asam absisat. Hormon pertumbuhan yang diproduksi dari dalam tumbuhan disebut hormon endogen. Hormon endogen ini disintesis pada jaringan meristematik antara lain daun, primordium cabang, akar dan biji yang sedang berkembang sedangkan hormon eksogen adalah zat pengatur tumbuh yang disintesis di luar tubuh tumbuhan (Dinda $d k k, 2016$ ).

\section{Interaksi Pupuk Daun Bayfolan dan ZPT Diameter Batang}

Hasil pengamatan diameter batang $(\mathrm{mm})$ tomat disajikan pada Tabel Lampiran 9, dan 11, sedangkan analisis sidik ragamnya masing-masing disajikan pada Tabel Lampiran 10, dan 12.

Hasil analisis sidik ragam menunjukkan bahwa interaksi antara pupuk daun Bayfolan dan ZPT berpengaruh nyata terhadap diameter batang $(\mathrm{mm})$ pada umur 30 HST. Rata - rata diameter batang $(\mathrm{mm})$ tomat akibat pengaruh pupuk daun bayfolan dan ZPT disajikan pada Tabel 5.

Tabel 5. Rata - rata Diameter Batang (mm) Tomat pada Umur 30 dan 60 HST akibat Perlakuan Pupuk Daun Bayfolan dan ZPT.

\begin{tabular}{|c|c|c|}
\hline \multirow{2}{*}{ Pupuk Daun Bayfolan dan ZPT } & \multicolumn{2}{|c|}{ Diameter Batang (mm) } \\
\cline { 2 - 3 } & $30 \mathrm{HST}$ & $60 \mathrm{HST}$ \\
\hline $\mathrm{D}_{0} Z_{1}$ & $7,33 \mathrm{bc}$ & 9,67 \\
\hline $\mathrm{D}_{0} Z_{2}$ & $7,58 \mathrm{c}$ & 9,75 \\
\hline $\mathrm{D}_{0} Z_{3}$ & $6,17 \mathrm{a}$ & 9,00 \\
\hline $\mathrm{D}_{1} Z_{1}$ & $7,17 \mathrm{bc}$ & 9,50 \\
\hline $\mathrm{D}_{1} Z_{2}$ & $6,83 \mathrm{abc}$ & 9,17 \\
\hline $\mathrm{D}_{1} Z_{3}$ & $7,17 \mathrm{bc}$ & 9,58 \\
\hline $\mathrm{D}_{2} Z_{1}$ & $7,50 \mathrm{bc}$ & 9,58 \\
\hline $\mathrm{D}_{2} Z_{2}$ & $6,92 \mathrm{abc}$ & 10,50 \\
\hline $\mathrm{D}_{2} Z_{3}$ & $6,67 \mathrm{ab}$ & 9,42 \\
\hline $\mathrm{D}_{3} Z_{1}$ & $6,67 \mathrm{ab}$ & 9,75 \\
\hline $\mathrm{D}_{3} Z_{2}$ & $6,67 \mathrm{ab}$ & 9,58 \\
\hline $\mathrm{D}_{3} Z_{3}$ & $7,17 \mathrm{bc}$ & 10,75 \\
\hline $\mathrm{BNT}_{0} 05$ & 0,86 & - \\
\hline
\end{tabular}

Keterangan : - Angka yang diikuti huruf yang sama berbeda tidak nyata pada uji BNT 5\%. 
Tabel 5 di atas menunjukkan bahwa pengaruh interaksi antara pupuk daun Bayfolan dan ZPT pada umur 30 HST tertinggi di jumpai pada perlakuan $\mathrm{D}_{0} \mathrm{Z}_{2}$ yang berbeda nyata dengan $\mathrm{D}_{0} \mathrm{Z}_{3}, \mathrm{D}_{2} \mathrm{Z}_{3}, \mathrm{D}_{3} \mathrm{Z}_{1}$, dan $\mathrm{D}_{3} \mathrm{Z}_{2}$, namun berbeda tidak nyata dengan $\mathrm{D}_{0} \mathrm{Z}_{1}, \mathrm{D}_{1} \mathrm{Z}_{1}, \mathrm{D}_{1} \mathrm{Z}_{2}$, $\mathrm{D}_{1} Z_{3}, \mathrm{D}_{2} \mathrm{Z}_{1}, \mathrm{D}_{2} \mathrm{Z}_{2}$, dan $\mathrm{D}_{3} \mathrm{Z}_{3}$. Di duga pada masa pertumbuhan awal umur 30 HST tanaman tomat dapat menyerap unsur hara yang diberikan melalui penyemprotan Bayfolan dan ZPT dengan baik, sehingga memacu pertumbuhan diameter batang.

\section{KESIMPULAN DAN SARAN}

\section{Kesimpulan}

1. Pupuk daun Bayfolan berpengaruh nyata terhadap tinggi tanaman pada umur 30 HST, produksi per plot, dan produksi per hektar, serta berpengaruh tidak nyata pada parameter lainnya. Perlakuan terbaik dijumpai pada $\mathrm{D}_{3}$ yaitu $3 \mathrm{ml} /$ liter air.

2. ZPT berpengaruh tidak nyata terhadap semua parameter pengamatan.

3. Interaksi antara pupuk daun Bayfolan dan ZPT berpengaruh nyata terhadap Diameter Batang pada umur $30 \mathrm{HST}$. Perlakuan terbaik dijumpai pada $\mathrm{D}_{0} \mathrm{Z}_{2}$ yaitu kontrol $(0 \mathrm{ml} /$ liter air) dan $0,2 \mathrm{ml} /$ liter air.

\section{Saran}

1. Untuk pertumbuhan dan produksi tanaman tomat yang baik dianjurkan menggunakan pupuk daun Bayfolan dengan konsentrasi $3 \mathrm{ml} /$ liter air.

2. Berdasarkan hasil penelitian ini, dianjurkan untuk mendapatkan pertumbuhan dan produksi yang baik dengan menggunakan dosis ZPT 0,2 ml/liter air.

3. Disarankan agar menggunakan dosis yang berlaku.

\section{DAFTAR PUSTAKA}

Asnijar, (2013). Pengaruh Varietas dan Konsentrasi Pupuk Bayfolan Terhadap Pertumbuhan dan Hasil Tanaman Cabai (Capsicum annum L.). [Jurnal], Alumni Program Studi Agroteknologi Fakultas Pertanian Universitas Syiah Kuala, Banda Aceh.

Aryu Atyya, (2012). Faktor Luar (Lingkungan). http://www. catatan-biologi. blogspot.co.id/2012/12/faktor-faktor-yang-mempengaruhi.html. Diakses pada tanggal 14 Maret 2016.

Admin, 2012. Benarkah Pupuk Daun Efektif. http://www. Gagas pertanian.com/2012/12/benarkah - pupuk - daun efektif. html\#ixzz3YzKQeKc5. Di akses 20 April 2020.

Alpano, 2014. Pengaruh Pemberian Giberelin Terhadap Poduktifitas Dua Varietas Tanaman Tomat (Lycopersicum esculentum Mill.). [Jurnal], Jurusan Budidaya Pertanian, Fakultas Pertanian, Universitas Brawijaya.

Bambang, 2008. Tomat, Usaha Tani Dan Penanganan Pascapanen. Kanisius, Yogyakarta. 
Dinda, Yuni, dan Evie, 2016. Pengaruh Pemberian Hormon Giberelin Terhadap Pertumbuhan Buah Secara Partenokarpi pada Tanaman Tomat Varitas Tombatu F1. [Jurnal] Jurusan Biologi, Fakultas Matematika dan Ilmu Pengetahuan Alam.Universitas Negeri Surabaya

Endang, 2014. Pertumbuhan Dan Perkembangan Tnaman Tomat.

Prasetyo, 2011. ZPT dan Zat Pengatur Tumbuhan (ZPT). $\quad$ http://llmutanah.blogspot.com/2011/12/ZPT-dan-zat-pengatur-tumbuhan-zpt.html. Di akses 17 Juli 2020.

Riyan, 2012. Buah Tomat. http://mipa-farmasi.blogspot.com/2012/02/buah-tomat.html. Di akses 29 April 2020.

Susmawati, 2014. Pupuk Daun Dan Aplikasinya Untuk Tanaman. http://bbppbinuang.info/news45-pupuk-daun-dan-aplikasinya-untuktanaman.html. Di akses 29 April 2020.

Yanaputra, 2010. Morfologi Tanaman. http://yanaputra81.blogspot.com/2010/02/morfologitumbuhan.html. Di akses 17 Juli 2020.

Zaka, 2015. Macam Zpt Tumbuhan, Fungsi, Dan Jenis. http://www.artikelsiana.com/2015/03/macam-ZPT-tumbuhan-fungsi-jenis.html. Di akses 17 Juli 2020. 